\title{
Fuzzy Hierarchical Selection Model of Tourism Development of Uninhabited Island of South China
}

\author{
Wei Huang ${ }^{1,2}$, Yanping Dai ${ }^{1}$, Ruwen Liang ${ }^{1}$, Yuanjun Huang ${ }^{1}$, Qiuhua Cheng ${ }^{1}$ and Daobo Wang ${ }^{1, *}$ \\ ${ }^{1}$ Research Center of Beibu Gulf Marine Culture, College of Resources \& Environment, Qinzhou University, China \\ ${ }^{2}$ College of agriculture, Guangxi University, China \\ Corresponding author
}

\begin{abstract}
Not only great tourism development value, but also huge risk for developing of uninhabited island. Scientific and reasonable planning and especially the choice of major tourism projects is one of the key factors of its success or not. Based on Qinzhou, the fuzzy selection model and clearing evaluation index system was used based on AHP, which determining the weights of different projects. Eight uninhabited islands were taken as the example to calculate the suitability of different project development in each island. The evaluation results is consistent with the guidance for the development and utilization of islands with no residents list by the State Oceanic Administration released in 2011, which show the research methods of China's uninhabited of the island development planning and management has certain theoretical significance and application value.
\end{abstract}

Keywords-beibu gulf; uninhabited island; development model; Eco tourism; project location; Qinzhou

\section{INTRODUCTION}

Uninhabited Island as an important part of marine resources, has a very important political, military and economic value, the development potential is huge. He et al found that there are some problems in the process of the development of tourism industry, such as low utilization efficiency, single project and poor project management [1]. Lacking of island utilization planning, and low level of utilization has become the obvious restricting factors of uninhabited island tourism in Xiamen [2]. Robertico pointed out that non-resident island should be allocated more resources to develop tourism industry, and to achieve the professional development of the tourism industry in the islands [3]. Tom recommended that operators and the relevant government departments should get together to improve the quality of tourism products and service efficiency, and promote tourism development in uninhabited island [4].

There are many researches on the island development model. Ma summed up two islands development model (regional linkage development and maturity of the orderly development) in the empirical research on the uninhabited island [5]. Miao et al discussed 4 modes of the key-developing, protecting- developing and exploitation of uninhabited island [6]. Zhang analyzed island tourism and proposed the thought of "land island integration" for island tourism [7].

As a part of the territory, the island has a very important strategic position. And also as the weak part of China's territory, the uninhabited island development is particularly prominent, and we should strengthen its development and management. However, there is lack of researches on the choice of the island tourism projects. Based on the northern Gulf region and taking uninhabited island as an example in Qinzhou, the tourism development services for the uninhabited island in this region was explored.

\section{MATERIALS AND METHODS}

\section{A. General Situation of the Research Area}

Qinzhou has 11 uninhabited islands in "China's first batch of the development and utilization of uninhabited of the island directory" listed by the State Oceanic Administration. Eight uninhabited islands was choosed for research, namely Dushanbei Island $\left(\mathrm{I}_{1}\right)$, Caren Island $\left(\mathrm{I}_{2}\right)$, Hudun Island $\left(\mathrm{I}_{3}\right)$, Hanjingchangling Island $\left(\mathrm{I}_{4}\right)$, Xiaodun Island $\left(\mathrm{I}_{5}\right)$, Zhangmuhuan Island $\left(\mathrm{I}_{6}\right)$, Xiaoermeiling Island $\left(\mathrm{I}_{7}\right)$ and Chaodun Island $\left(\mathrm{I}_{8}\right)$.

Based on the successful cases of uninhabited island tourism development at home and abroad, considering the situations of uninhabited island in Qinzhou, the article points out 5 island tourism development models, namely Sightseeing \& Recreation $\left(A_{1}\right)$, Leisure \& vacation $\left(A_{2}\right)$, Sports \& Entertainment $\left(\mathrm{A}_{3}\right)$, Scientific research $\left(\mathrm{A}_{4}\right)$, Ecological protection $\left(\mathrm{A}_{5}\right)$. And then develop Eco-tourism project with regional characteristics and national features and characteristics of marine.

\section{B. Fuzzy Selection Model}

1) Determine the evaluation index system. During construct of evaluation index system of non-resident island tourism development mode, in order to achieve the effectiveness of the selection of indicators, it should be adhered to the principles of the combination of fuzzy and precision, system and the typical, science and operability, qualitative and quantitative analysis.

Set evaluation target as $U$, evaluation elements $u_{i}$ as a subset, the evaluation factor layer $u_{i j}$ as the subset $u_{i}$, evaluation factor sub layer $u_{i j z}$ as the evaluation of the subset of the factor layer $\mathrm{u}_{\mathrm{ij}}$, where $\mathrm{i}, \mathrm{j}, \mathrm{z}$ represent quantity.

$$
\begin{aligned}
& \mathrm{U}=\left\{u_{1}, u_{2}, \cdots, \mathrm{u}_{\mathrm{i}}\right\} \\
& \mathrm{u}_{\mathrm{i}}=\left\{u_{\mathrm{i} 1}, u_{\mathrm{i} 2}, \cdots, \mathrm{u}_{\mathrm{ij}}\right\}
\end{aligned}
$$




$$
\mathrm{u}_{\mathrm{ij}}=\left\{u_{\mathrm{ij} 1}, u_{i j 2}, \cdots, \mathrm{u}_{\mathrm{ijz}}\right\}
$$

2) Evaluation level. In this article, $\mathrm{V}$ was used to express the evaluation set: in which $\mathrm{n}$ is the total number of the evaluation results, the evaluation set can be determined according to the actual situation, and the difference level totals 9 which is divided from 1 to 9 .

$$
\mathrm{V}=\left\{v_{1}, v_{2}, \cdots, v_{\mathrm{i}}\right\}
$$

3) Set up the Fuzzy relation matrix. To determine the degree of membership of $\mathrm{V}$ needs to start from each of the factors, commonly referred to as the single factor fuzzy evaluation method..then,from each factor $u_{i}(i=1,2, \cdots, m)$,to quantify the object to be evaluated one by one, get the Fuzzy relation matrix $\mathrm{R}$.

$$
\mathrm{R}=\left[\begin{array}{cccc}
\mathrm{r}_{11} & \mathrm{r}_{12} & \cdots & \mathrm{r}_{1 \mathrm{n}} \\
\mathrm{r}_{21} & \mathrm{r}_{21} & \cdots & \mathrm{r}_{1 \mathrm{n}} \\
\vdots & \vdots & \ddots & \vdots \\
\mathrm{r}_{\mathrm{m} 1} & \mathrm{r}_{\mathrm{m} 2} & \cdots & \mathrm{r}_{\mathrm{mn}}
\end{array}\right]
$$

In Matrix $\mathrm{R}, \mathrm{r}_{\mathrm{ij}}$ (according to the factors $\mathrm{u}_{\mathrm{i}}$ to measure membership degree of fuzzy subset of $v_{j}$.) and $u_{i}$ is reflected by the $r_{i}, r_{i}$ is expressed as a single factor evaluation matrix ,which can be seen as a fuzzy relation between factor set $\mathrm{U}$ and evaluation set $\mathrm{V}$. That is the reasonable relationship between the influencing factors and the evaluation objects. In the determination of membership, this article uses the expert scoring method, which is used to score the results of statistics, model as follows,

$$
\mathrm{r}_{i j}=\left\{\begin{array}{c}
1,(i=j) \\
1-c \sum_{k=1}\left|x_{i k}-x_{j k}\right|,(i \neq j)
\end{array}\right.
$$

c for adjustment coefficient, make sure $0 \leqslant \mathrm{r}_{\mathrm{ij}} \leq 1$.

4) Fuzzy weight vector of evaluation factors. Each factor is corresponding to a weight coefficient $a_{i}(i=1,2, \ldots, m)$, and $\mathrm{a}_{\mathrm{i}}$ is nonnegative and satisfies $\sum \mathrm{a}_{\mathrm{i}}=1$, fuzzy set $\mathrm{A}$ represents a weight set, It is composed of a number of $i$ factors. Weights directly affect the effect of the decision, so it is very important In this article, the analytic hierarchy process (AHP) is used to calculate the weight coefficient in the Yaahp 10.3 software.

5) Multi factor fuzzy evaluation. The model of fuzzy comprehensive evaluation is as follows:

$$
B=A \cdot R=\left(a_{1}, a_{2}, \cdots, a_{m}\right)\left[\begin{array}{cccc}
\mathrm{r}_{11} & \mathrm{r}_{12} & \cdots & \mathrm{r}_{1 \mathrm{n}} \\
\mathrm{r}_{21} & \mathrm{r}_{21} & \cdots & \mathrm{r}_{1 \mathrm{n}} \\
\vdots & \vdots & \ddots & \vdots \\
\mathrm{r}_{\mathrm{m} 1} & \mathrm{r}_{\mathrm{m} 2} & \cdots & \mathrm{r}_{\mathrm{mn}}
\end{array}\right]=\left(b_{1}, b_{2}, \cdots, b_{n}\right)
$$

where $b_{j}(j=1,2, \cdots, n)$ was obtained by operating the $j$ column of $A$ and $R$, which expresses the membership degree of rated object on vj fuzzy subset on the whole. The algorithm of fuzzy synthesis operator $M(\wedge, \vee)$ is as follows,

$$
\mathrm{b}_{j}=\underset{i=1}{\stackrel{m}{\vee}}\left(a_{i} \wedge r_{i j}\right)=\max _{1 \leq i \leq m}\left\{\min \left(a_{i}, r_{i j}\right)\right\}, j=1,2, \cdots, n
$$

6) Analysis and decision of evaluation results. The result of fuzzy comprehensive evaluation is a vector, which reflects the degree of membership of the fuzzy subset. In this article,

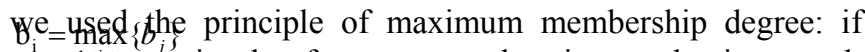
$\mathrm{V}_{\mathrm{i}} \operatorname{li}_{1 \leq \mathrm{j} \leq n}\left\{b_{j}\right\}$ in the fuzzy comprehensive evaluation result vector $B=\left(b_{1}, b_{2}, \cdots, b_{n}\right)$, then generally speaking, the object of evaluation is subordinate to i level.

\section{RESULTS AND ANALYSIS}

\section{A. Evaluation Index System}

Index selections using expert evaluation method, 20 experts and scholars in related fields were invited to consulate and score the degree of correlation factor layer and element layer on the initial evaluation system, including the tourism practitioners, tourists. According to the experts, it is recommended to increase and refine the evaluation index of

\begin{tabular}{|c|c|c|c|}
\hline $\begin{array}{l}\text { Target } \\
\text { layer }\end{array}$ & Element layer & \multicolumn{2}{|c|}{ Evaluation factor layer } \\
\hline \multirow{31}{*}{$\begin{array}{l}\text { A1 } \\
(\text { or A2; } \\
\text { or A3; } \\
\text { or A4; } \\
\text { or A5) }\end{array}$} & \multirow{7}{*}{$\begin{array}{l}\text { Resource and } \\
\text { environmental } \\
\text { conditions } \\
\text { B1 }\end{array}$} & \multirow{5}{*}{$\begin{array}{l}\text { Basic } \\
\text { condition } \\
\text { C1 }\end{array}$} & original nature of Resource D1 \\
\hline & & & Richness of Resource D2 \\
\hline & & & Island visibility D3 \\
\hline & & & Cultural character D4 \\
\hline & & & Characteristic D5 \\
\hline & & \\
\hline & & \multicolumn{2}{|c|}{$\begin{array}{l}\text { Ecological environmental risk factors } \mathrm{C} 2 \\
\text { Ecological environment protection measures } \mathrm{C} 3\end{array}$} \\
\hline & \multirow{6}{*}{$\begin{array}{l}\text { Touris } \\
\text { develo } \\
\text { value } \\
\text { B2 }\end{array}$} & \multicolumn{2}{|c|}{ Ornamental value $\mathrm{C} 4$} \\
\hline & & \multicolumn{2}{|c|}{ ecological value C5 } \\
\hline & & \multicolumn{2}{|c|}{ Health value $\mathrm{C} 6$} \\
\hline & & \multicolumn{2}{|c|}{ Entertainment value C7 } \\
\hline & & \multicolumn{2}{|c|}{ Scientific value of scientific research C8 } \\
\hline & & \multicolumn{2}{|c|}{ Economic resources value C9 } \\
\hline & \multirow{18}{*}{$\begin{array}{l}\text { Tourism } \\
\text { development } \\
\text { conditions } \\
\text { B3 }\end{array}$} & \multicolumn{2}{|c|}{\begin{tabular}{l|l} 
transportation & Convenient an \\
\end{tabular}} \\
\hline & & \multicolumn{2}{|c|}{\begin{tabular}{l|l} 
& \\
condition & Distance D7
\end{tabular}} \\
\hline & & $\mathrm{C} 10$ & Transportation costs D8 \\
\hline & & \multirow{5}{*}{$\begin{array}{l}\text { Infrastructu } \\
\text { re } \\
\text { C11 }\end{array}$} & Accommodation conditions D9 \\
\hline & & & Food \&beverage conditions D10 \\
\hline & & & Entertainment facilities D11 \\
\hline & & & Sports facilities D12 \\
\hline & & & Other infrastructure D13 \\
\hline & & \multicolumn{2}{|c|}{ Regional economic development $\mathrm{C} 12$} \\
\hline & & \multicolumn{2}{|c|}{ Investment dynamics $\mathrm{C} 13$} \\
\hline & & \multirow{3}{*}{$\begin{array}{l}\text { market } \\
\text { demand } \\
\mathrm{C} 14\end{array}$} & Local market demand D14 \\
\hline & & & Domestic market demand D15 \\
\hline & & & Overseas market demand D16 \\
\hline & & \multirow{3}{*}{$\begin{array}{l}\text { Policy } \\
\text { support } \\
\text { C15 }\end{array}$} & Local policy support D17 \\
\hline & & & Beibu Gulf policy support D18 \\
\hline & & & National policy support D19 \\
\hline & & \multicolumn{2}{|c|}{ Project planning $\mathrm{C} 16$} \\
\hline & & \multicolumn{2}{|c|}{ Marketing strategy rationality $\mathrm{C} 17$} \\
\hline
\end{tabular}
the island's own resources, and improve the value of tourism development. Ultimately determined the evaluation index system was shown in TABLE I.

TABLE I. EVALUATION INDEX SYSTEM OF TOURISM DEVELOPMENT OF UNINHABITED ISLAND IN QINZHOU 


\section{B. Evaluation Index Weight}

7) AHP model. AHP model of sightseeing and recreation(or other objects) island tourism development model was shown in TABLE I.

8) Structure judgment matrix and consistency checking. Give the evaluation index system and the reference evaluation scale to the expert; combining with professional knowledge and practical experience, let them determine the relative importance of each index of five development modes of the layer by judgment matrix method evaluation, and then do consistency test of evaluation index system.

Yaaph was used to enter the AHP evaluation results from the experts, and use marking correction function to adjust the consistency of the judgment matrix. After adjustment, the consistency index (CR) of each index is less than 0.1 , that is, the relative importance of each index is acceptable and the data is valid. Calculate the consistency ratio of the remaining four development models by the same method.

9) Index weight. After determining the consistency of the five development models, Yaaph was used to calculate the weight of each evaluation index. Calculate the weight of the five development models, the weight of evaluation index system of uninhabited island tourism development model of Qinzhou shown in TABLE II.

TABLE II. WEIGHT OF EACH INDEX IN THE FIVE DEVELOPMENT MODELS

\begin{tabular}{|c|c|c|c|c|c|c|c|}
\hline Criterions lay & index & & $\mathrm{W}_{\mathrm{A} 1}$ & $\mathbf{W}_{\mathrm{A} 2}$ & $\mathbf{W}_{\mathrm{A3}}$ & $\mathrm{W}_{\mathrm{A} 4}$ & $\mathbf{W}_{\mathrm{A5}}$ \\
\hline \multirow{8}{*}{ B1 } & & D1 & 0.0030 & 0.0011 & 0.0017 & 0.0058 & 0.0054 \\
\hline & & D2 & 0.0021 & 0.0067 & 0.0009 & 0.0051 & 0.0050 \\
\hline & $\mathrm{C} 1$ & D3 & 0.0094 & 0.0024 & 0.0046 & 0.0007 & 0.0010 \\
\hline & & D4 & 0.0016 & 0.0021 & 0.0005 & 0.0026 & 0.0009 \\
\hline & & D5 & 0.0059 & 0.0082 & 0.0028 & 0.0025 & 0.0010 \\
\hline & $\mathrm{C} 2$ & & 0.0542 & 0.0408 & 0.0209 & 0.0281 & 0.0386 \\
\hline & $\mathrm{C} 3$ & & 0.1337 & 0.0816 & 0.0419 & 0.1186 & 0.1114 \\
\hline & $\mathrm{C} 4$ & & 0.1536 & 0.1508 & 0.0297 & 0.0165 & 0.0647 \\
\hline \multirow{5}{*}{ B2 } & $\mathrm{C} 5$ & & 0.0677 & 0.0423 & 0.0291 & 0.0886 & 0.2543 \\
\hline & C6 & & 0.0559 & 0.1686 & 0.0115 & 0.0118 & 0.0327 \\
\hline & C7 & & 0.1860 & 0.0942 & 0.1142 & 0.0304 & 0.0190 \\
\hline & C8 & & 0.0544 & 0.0395 & 0.0131 & 0.1233 & 0.1343 \\
\hline & C9 & & 0.0323 & 0.0760 & 0.0584 & 0.0263 & 0.0347 \\
\hline \multirow{18}{*}{ B3 } & & D6 & 0.0209 & 0.0339 & 0.1206 & 0.1105 & 0.0507 \\
\hline & $\mathrm{C} 10$ & D7 & 0.0058 & 0.0064 & 0.0227 & 0.0208 & 0.0095 \\
\hline & & D8 & 0.0063 & 0.0120 & 0.0427 & 0.0392 & 0.0180 \\
\hline & & D9 & 0.0047 & 0.0030 & 0.0148 & 0.0195 & 0.0038 \\
\hline & & D10 & 0.0022 & 0.0056 & 0.0064 & 0.0241 & 0.0064 \\
\hline & C11 & D11 & 0.0068 & 0.0154 & 0.0139 & 0.0377 & 0.0116 \\
\hline & & D12 & 0.0006 & 0.0019 & 0.0827 & 0.0063 & 0.0023 \\
\hline & & D13 & 0.0015 & 0.0024 & 0.0152 & 0.0171 & 0.0112 \\
\hline & $\mathrm{C} 12$ & & 0.0188 & 0.0105 & 0.0430 & 0.0418 & 0.0112 \\
\hline & $\mathrm{C} 13$ & & 0.0173 & 0.0408 & 0.0547 & 0.0521 & 0.0308 \\
\hline & & D14 & 0.0418 & 0.0268 & 0.0736 & 0.0416 & 0.0209 \\
\hline & $\mathrm{C} 14$ & D15 & 0.0139 & 0.0151 & 0.0385 & 0.0218 & 0.0109 \\
\hline & & D16 & 0.0070 & 0.0034 & 0.0101 & 0.0057 & 0.0029 \\
\hline & & D17 & 0.0055 & 0.0053 & 0.0240 & 0.0424 & 0.0190 \\
\hline & $\mathrm{C} 15$ & D18 & 0.0028 & 0.0010 & 0.0045 & 0.0080 & 0.0036 \\
\hline & & D19 & 0.0014 & 0.0019 & 0.0085 & 0.0150 & 0.0067 \\
\hline & $\mathrm{C} 16$ & & 0.0314 & 0.0439 & 0.0753 & 0.0180 & 0.0692 \\
\hline & $\mathrm{C} 17$ & & 0.0515 & 0.0565 & 0.0195 & 0.0180 & 0.0083 \\
\hline
\end{tabular}

From table II, the factors weight ranking order of Sightseeing \& Recreation island tourism development model is B2> B3 $>$ B1. This means that the potential value of tourism development is more important. The greatest value of the weight is $\mathrm{C} 7$, followed by $\mathrm{C} 4$ and $\mathrm{C} 3$, which meet the needs of tourists to enjoy the island's tourism resources, but also to achieve the purpose of pleasure and experience through recreational projects or facilities, the development should also pay attention to the protection of ecological environment.

The factors weight ranking order of Leisure \& vacation island tourism development model is B2> B3> B1.This means that the potential value of tourism development is more important than the condition of tourism development. Weight of the maximum value is $\mathrm{C} 6$, followed by $\mathrm{C} 4$ and $\mathrm{C} 7$. Leisure resort is focused on the use of island natural resources and tourism facilities and services, providing tourists with a good travel experience, so that visitors can achieve physical comfort, spiritual relaxation and spiritual enjoyment of leisure vacation experience.

The factors weight ranking order of Sports \& entertainment island tourism development model is $\mathrm{B} 3>\mathrm{B} 2>\mathrm{B} 1$. Developing sports and entertainment projects more rely on the original natural resources, environment, transportation and other elements, so tourism development conditions are more important. The weight of the maximum value is D6, followed by $\mathrm{C} 7$ and D12. Under the same conditions, the entertainment value is more attractive than the sports facilities.

The factors weight ranking order of Scientific research island tourism development model is B3>B2>B1. The maximum value of the weight is $\mathrm{C} 8$, followed by $\mathrm{C} 3$ and $\mathrm{D} 6$. Scientific research Island with a strong ecological environment protection measures focuses on scientific research and popular science education. And convenient transportation will be conducive to the number of visitors.

The factors weight ranking order of Ecological protection island tourism development model is $\mathrm{B} 2>\mathrm{B} 3>\mathrm{B} 1$. The greatest value of the weight is $\mathrm{C} 5$, followed by $\mathrm{C} 8$ and $\mathrm{C} 3$. Ecological Protection Island has high ecological value and scientific research value because of its rarity and special resources and its environment is fragile.

\section{Selection of Development Model}

Based on the index weight, constructing fuzzy comprehensive evaluation model, and uses the fuzzy synthesis operator $\mathrm{M}(\wedge, \vee)$, got the uninhabited island tourism development model evaluation grade of Qinzhou, results are shown in TABLE III.

TABLE III. EVALUATION LEVEL OF TOURISM DEVELOPMENT MODEL FOR UNINHABITED ISLANDS

\begin{tabular}{|c|c|c|c|c|c|c|c|c|}
\hline & $\mathrm{I}_{1}$ & $\mathrm{I}_{2}$ & $\mathrm{I}_{3}$ & $\mathrm{I}_{4}$ & $\mathrm{I}_{5}$ & $\mathrm{I}_{6}$ & $\mathrm{I}_{7}$ & $\mathrm{I}_{8}$ \\
\hline $\mathrm{A}_{1}$ & $7.63 \mathrm{a}$ & $5.86 \mathrm{c}$ & $5.68 \mathrm{c}$ & 6.63 & 5.57 & $7.39 \mathrm{a}$ & $6.68 \mathrm{a}$ & $6.05 \mathrm{a}$ \\
\hline $\mathrm{A}_{2}$ & $7.47 \mathrm{~b}$ & $6.00 \mathrm{a}$ & $5.66 \mathrm{c}$ & $6.86 \mathrm{c}$ & $5.77 \mathrm{c}$ & $7.35 \mathrm{a}$ & $6.64 \mathrm{a}$ & 6.03 \\
\hline $\mathrm{A}_{3}$ & 7.11 & 5.82 & $5.76 \mathrm{a}$ & $7.07 \mathrm{a}$ & $5.95 \mathrm{a}$ & $7.21 \mathrm{~b}$ & 6.25 & 5.93 \\
\hline $\mathrm{A}_{4}$ & 7.08 & 5.65 & 5.47 & 6.49 & 5.70 & 6.61 & 6.02 & 5.93 \\
\hline $\mathrm{A}_{5}$ & $7.41 \mathrm{c}$ & $5.99 \mathrm{a}$ & 5.56 & 6.60 & 5.35 & 6.81 & $6.62 \mathrm{~b}$ & 5.96 \\
\hline \multicolumn{7}{|c|}{$\begin{array}{c}\text { a is thest suitable for the island's development model; b is better for the } \\
\text { island's development model; c is a little more suitable for the island's development } \\
\text { model. }\end{array}$} \\
\hline
\end{tabular}

As could be seen from the table $3, \mathrm{I}_{1}, \mathrm{I}_{6}, \mathrm{I}_{7}$ and $\mathrm{I}_{8}$ are most suitable of sightseeing and recreation island tourism 
development model. $\mathrm{I}_{6}, \mathrm{I}_{7}$ and $\mathrm{I}_{2}$ are the most suitable leisure resort island tourism development model. $\mathrm{I}_{3}, \mathrm{I}_{4}$ and $\mathrm{I}_{5}$ are the most suitable for sports entertainment island tourism development mode. $I_{2}$ is also the most suitable for the development of Eco Tourism. $\mathrm{I}_{1}$ and $\mathrm{I}_{8}$ are more suitable for leisure vacation island tourism development model. $\mathrm{I}_{6}$ is suitable for sports entertainment tourism development model, $\mathrm{I}_{7}$ is more suitable for the development of Eco tourism development model; $I_{2}$ and $I_{3}$ are a little suitable for recreation island tourism development model. $\mathrm{I}_{3}, \mathrm{I}_{4}$ and $\mathrm{I}_{5}$ are also more suitable for sightseeing island tourism development mode. At the same time $I_{5}$ is also a little suitable and only suitable for scientific research on the island tourism development model. $\mathrm{I}_{1}$ is a little more suitable for scientific research of the island tourism development model.

\section{DISCUSSION AND CONCLUSION}

Scholars at home and abroad have carried out a lot of research on the development of uninhabited island. For example, $\mathrm{Su}$ ting used the mutual exclusion matrix to determine the development and utilization of uninhabited of the island [8], Lin et al. determined the suitability of the development of uninhabited island by the ecological importance development feasibility mutual exclusion matrix [9]. Zhu et al. constructed the evaluation index system of sustainable development of uninhabited island in Qingdao respectively [10]. But they are not related to the development model of uninhabited island, but its research ideas and research methods are worth learning from.On the basis of previous studies, using AHP based on the fuzzy selection model, this article extended the idea of solving practical problems, overcome the shortage of single level analysis method and make an objective evaluation on the research.

From the driving factors of island tourism development, based on a full understanding of the basic situation of uninhabited island in Qinzhou. This article pointed five island tourism development modes--the sightseeing, recreation and holiday, sports entertainment, science research and ecological protection. Using the expert evaluation method, the final evaluation index model is determined from 3 aspects: the island resource environment condition, the tourism development value and the tourism development condition. That is 5 target level, 3 factor level, and 31 evaluation indexes. The method not only contains the key evaluation indicators of different development models, but also contains the evaluation factors such as traffic conditions, infrastructure, and market demand and so on. Then with the same set of evaluation model by AHP and expert consultation, the weights of evaluation factor were calculated about five development modes. And finally different weights were obtained by different development patterns in the same evaluation index system evaluation model. Compared with previous studies, this system covers three aspects: the basic resources and environmental conditions, development status and development potential of the island. It is a comprehensive description of the island's property; the evaluation index is more detailed and specific. Therefore, uninhabited of the island tourism development model evaluation index system should have the key evaluation index and the assisted evaluation index which influences the selection of development mode. By this, it makes the evaluation index system more perfect. At the same time, the different development models use the same index system. According to the different development mode, the relative importance of the indicators is different, and the different weight coefficients can influence the final evaluation results. This method has obvious advantages in the evaluation; according to their own conditions each island can obtain each kind of development mode score in the same evaluation index system with different weights. And finally each island can get the most suitable, the more suitable, suitable development of evaluation mode then in this way it can avoid the wrong evaluation caused by different evaluation index of different development patterns.

In addition, the same set of evaluation system with different weights, fully reflects which the different development models focus on the evaluation, and this makes the results with a strong practical more reasonable ,more scientific.

Therefore, this study will serve as a model for uninhabited island tourism development in Qinzhou and the Northern Gulf and also as a reference for other regions to develop island tourism. And it will provide the basis and reference value for the development of uninhabited island tourism in the Beibu Gulf region from the construction of model and evaluation index system in the study area.

\section{ACKNOWLEDGMENT}

Thanks to the following funds: Key Project of Research Center of Beibu Gulf Marine Culture (2015BMCC04); Science and Technology Research Project of Guangxi Universities in 2015 (KY2015LX525).

\section{REFERENCES}

[1] F. He, Z. Quan, and M. Wang. "No residents of the island tourism development and design in Liaoning Province". J Liaoning Institute of Sci. \& Tech, vol. 13, pp. 50-52, Sep 2011.

[2] F. M. Huang, ang Z. Xie. "Current situation of development and utilization, Management and Protection Countermeasures of uninhabited island in Xiamen City”. J Appl. Ocean., vol. 22, pp. 531-536, Nov 2003.

[3] R. Croes. "Tourism specialization and economic output in small islands". Tourism Review, vol. 68 (4).pp. 34-48, Nov 2013.

[4] T. Baum. "Human Resource Management in Tourism:A Small Island Per- spective". Int. J Cultu, Touris \& Hos Res., vol. 6, pp. 124-132, May 2012.

[5] L. Ma. "The characteristics and development mode of island tourism destination". Econ Geog, vol. 31, pp. 1740-1744, Oct 2011.

[6] Z. Miao, Z. Chen, D. Cui, and et al. "Uninhabited island development and utilization of the existing problems and development mode of Zhoushan”. Anh. Agr. Sci., vol. 41, PP. 6108-6110. July 2013.

[7] H. Wang, Y. Zhu, and L. Wang. "The construction of the tourism development model of the nonresident islands in Liaoning Province". J Beij. Int. Lang. Uni., pp. 59-65, Sep 2012.

[8] T. Su. "Status and the development of the resource environment of uninhabited of the island of Shanghai City". Doctoral thesis in Shanghai Ocean University, July 2011.

[9] Z. Lin, N. Huang, Q. Chen, and et al. "The establishment of suitability evaluation index system for the development of uninhabited island and the application of the Xiamen sea area". J Appl. Ocean., vol. 31, pp. 136-142. March 2012.

[10] Z. Zhu, D. Guo, Y. Chen, and et al. "No residents of the island tourism development suitability evaluation of Qingdao City". Marine development \& management, Vol.32, pp. 112-116, March 2015. 